Article

\title{
Zircon U-Pb-Hf Isotopic and Trace Element Analyses for Oceanic Mafic Crustal Rock of the Neoproterozoic-Early Paleozoic Oeyama Ophiolite Unit and Implication for Subduction Initiation of Proto-Japan Arc
}

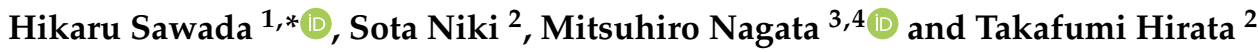 \\ 1 X-Star, Japan Agency of Marine-Earth Science and Technology (JAMSTEC), 2-15 Natsushima-cho, \\ Yokosuka 237-0061, Japan \\ 2 Geochemical Research Center, The University of Tokyo, 7-3-1 Hongo, Bunkyo-ku, Tokyo 113-0033, Japan; \\ niki@eqchem.s.u-tokyo.ac.jp (S.N.); hrt1@eqchem.s.u-tokyo.ac.jp (T.H.) \\ 3 Graduate School of Science and Engineering, University of Toyama, 3190 Gofuku, Toyama 930-8555, Japan; \\ nagata.mitsuhiro@jaea.go.jp \\ 4 Tono Geoscience Center, Japan Atomic Energy Agency (JAEA), Jorinji, Izumicho, Toki 509-5102, Japan \\ * Correspondence: hsawada@jamstec.go.jp
}

check for updates

Citation: Sawada, H.; Niki, S.; Nagata, M.; Hirata, T. Zircon $\mathrm{U}-\mathrm{Pb}-\mathrm{Hf}$ Isotopic and Trace Element Analyses for Oceanic Mafic Crustal Rock of the Neoproterozoic-Early Paleozoic Oeyama Ophiolite Unit and Implication for Subduction Initiation of Proto-Japan Arc. Minerals 2022, 12, 107. https:// doi.org/10.3390/min12010107

Academic Editors: Victoria B. Ershova, Artem V. Moiseev and Andrey K. Khudoley

Received: 24 December 2021

Accepted: 14 January 2022

Published: 17 January 2022

Publisher's Note: MDPI stays neutral with regard to jurisdictional claims in published maps and institutional affiliations.

Copyright: (c) 2022 by the authors. Licensee MDPI, Basel, Switzerland. This article is an open access article distributed under the terms and conditions of the Creative Commons Attribution (CC BY) license (https:/ / creativecommons.org/licenses/by/ $4.0 /)$.

\begin{abstract}
The Oeyama ophiolite unit is one of the oldest components of the subduction orogenic belts in the Japanese Islands and is important for understanding the initiation of plate subduction in the proto-Japan region. This study performed $\mathrm{U}-\mathrm{Pb}$ and $\mathrm{Lu}-\mathrm{Hf}$ isotopic and trace element analyses of zircon in gabbroic rocks from the Oeyama mafic-ultramafic complex, the type locality of the Oeyama ophiolite unit. This study obtained a weighted average zircon ${ }^{206} \mathrm{~Pb} /{ }^{238} \mathrm{U}$ age of $544 \pm 4 \mathrm{Ma}$, which indicates an igneous age of the gabbroic rock. Trace element analysis of the zircons revealed that the host rock was derived from the mantle depleted of incompatible elements such as the depleted mid-oceanic ridge mantle. The present igneous age and geochemical features of the zircons are consistent with previous work for other parts of the Oeyama ophiolitic unit. The isotopic signature of Hf also indicated that the gabbroic rock was derived from the depleted mantle domain. The Hf isotopic signature is more depleted than those represented by zircons in the jadeitite associated with the Oeyama ophiolite unit. These results demonstrated that the older crustal material was involved in the initial oceanic plate subduction along the proto-Japan arc.
\end{abstract}

Keywords: zircon; Hf isotope; trace element; ophiolite; subduction; Japan

\section{Introduction}

Ophiolites are fragments of oceanic lithosphere, including ultramafic rocks of the upper mantle and oceanic crustal mafic rocks preserved in the subduction continental margins or continental collision zones [1,2]. Although there are several types of ophiolite formation mechanisms, intra-oceanic forearcs with mid-oceanic ridge (MOR)-like magmatism are especially important tectonic activity for initiation of subduction and subsequent orogenic crustal evolution [3]. In southwest Japan, which has developed as a subduction orogenic belt since the late Proterozoic [4-7], the oldest subduction-related component is the ca. 540 Ma Oeyama ophiolite unit, which has a MOR-like geochemical signature [8]. The ophiolite has been considered as a fragment of the oceanic crust of the Panthalassa Ocean, which formed after ca. 800-700 Ma rifting of the Rodinia Supercontinent [9,10]. The oldest occurrences of high $\mathrm{P} / \mathrm{T}$-type metamorphic rocks (jadeitite) and subduction-related continental igneous rocks (granitoid) are ca. 530-500 Ma Cambrian [11-14], following the formation of the Oeyama ophiolite unit. The jadeitites have been reported as blocks in serpentinite mélange structurally under the Oeyama ophiolite unit. The jadeitite is monomineralic high P/T-type metasomatic rock composed of jadeite, which occurred in the subduction channel and the mantle wedge 
during serpentinization [15]. Therefore, the Oeyama ophiolite unit is key to understanding the initiation of plate subduction in the proto-Japan region.

The combination of $\mathrm{U}-\mathrm{Pb}$ dating and $\mathrm{Lu}-\mathrm{Hf}$ isotopic analysis for zircon is a powerful method for revealing the history of the incorporation of ophiolites into continental crust. Although the dating of ophiolite units has been relatively difficult because of the lack of datable minerals in ultramafic rocks, $\mathrm{U}-\mathrm{Pb}$ dating of zircon from associated gabbros, plagiogranites, anorthosites, and albitites is recently available (e.g., [16-22]). Dating studies for zircon from such rocks provides the determination of the magma crystallization to form the oceanic crust. On the other hand, as many ophiolite units have suffered tectonic disruption, igneous intrusion, and metamorphic events, it is often difficult to distinguish the origin of mafic rocks. The zircon Lu-Hf isotopic and trace element analyses can identify how the source mantle of the host rock is enriched or depleted in incompatible elements (e.g., [23-28]). In Japan, although many studies of zircon $\mathrm{U}-\mathrm{Pb}$ dating for the Paleozoic, Mesozoic, and even Cenozoic ophiolitic units have been widely reported (e.g., [8,29-33]), Lu-Hf isotopic analysis has not been done so far. In the Oeyama ophiolite unit, only $\mathrm{U}-\mathrm{Pb}$ age has been reported from gabbroic rocks of the oceanic crust [8], while both $\mathrm{U}-\mathrm{Pb}$ dating and Hf isotopic analysis have been performed for the associated jadeitite [34]. The jadeitite contains more zircon grains than the gabbroic rocks, and both metasomatic and igneous zircons were recovered from them [35,36]. Although, based on $\mathrm{U}-\mathrm{Pb}$ dating and $\mathrm{Hf}$ isotopic analyses, the protolith of the jadeitite has been considered to be a mixture of continental crustal material and mafic-ultramafic material with high Hf isotopic values [34], the entity of the protolith is still unclear. Moreover, polarity of subduction initiation along the proto-Japan arc has been debated whether it was oceanward or landward (e.g., $[4,5,8,37])$. Comparison of the newly obtained zircon U-Pb-Hf isotoic data of the Oeyama ophiolite unit and those of the associated jadeitite can help in understanding these discussions in the initiation of plate subduction along the proto-Japan arc.

Here the present study reports newly obtained $\mathrm{U}-\mathrm{Pb}, \mathrm{Lu}-\mathrm{Hf}$, and trace element analyses of zircon from garbbroic rocks from the Oeyama mafic-ultramafic complex, which is the type locality of the Oeyama ophiolite unit. These new results provide insights into the origin of the ophiolite and the earliest geotectonic evolution of the proto-Japan region.

\section{Geological Background}

The Oeyama ophiolite unit is a part of the Sangun Belt in the Inner Zone of Southwest Japan (Figure 1) covering all other units as a nappe in the belt. The ophiolite unit is presently distributed towards the WSW direction of the Oeyama mafic-ultramafic body, in the Izushi, Sekinomiya, Wakasa, Osayama, Ochiai-Hokubo, Ashidachi, Tari-Misaka, and Saijo bodies. The surrounding proper Sangun Belt is composed of high P/T metamorphic rocks. Tectonized fragments of the Oeyama ophiolite unit are scattered along the northeast of the Oeyama mafic-ultramafic complex to the Itoigawa-Omi area associated with the Range Belt [38].

According to a geological study by Kurokawa (1985) [39], the Oeyama ophiolite unit is composed of three units: Unit I ( $82 \mathrm{vol} \%$ ) is a tectonized ultramafic rock with the lowest cumulate unit that consists of dunite, harzburgite, and podiform chromitite. Unit II (15 vol\%) is ultramafic to mafic metamorphic rocks that were cumulate rocks in origin and suffered the epidote-amphibolite-facies metamorphism. Unit III (3 vol\%) contains coarse-grained metagabbro and diabase metamorphosed up to greenschist facies. The meta-cumulate of Unit II is suggested to be the tectonic block and differs from the surrounding ultramafic rocks of Unit I in origin [40]. The metamorphic grade of Unit III is lower than that of Unit II. The dominant occurrence of the ultramafic rocks of Unit I of the Oeyama ophiolite body indicates that the lower part of the typical ophiolitic sequence was preserved in the Oeyama ophiolite unit. The Oeyama mafic-ultramafic complex is the type section of the Oeyama ophiolite unit and the present study area [39]. The Oeyama mafic-ultramafic body is exposed as a nappe for ca. $4-5 \mathrm{~km}$ in the N-S width and ca. $10-12 \mathrm{~km}$ in the E-W width between the Paleogene Maizuru Granite and Permian accretionary complex of the Mino-Tanba Belt (Figure 1).

Kimura and Hayasaka (2019) [8] reported zircon U-Pb age of 545.4 $\pm 2.6 \mathrm{Ma}$ and $532.4 \pm 3.1 \mathrm{Ma}$ for the metagabbro of Unit III in the Saijo body. Other previous dating studies 
reported $\mathrm{K}-\mathrm{Ar}$ ages for hornblende from mafic or ultramafic rocks in the Oeyama ophiolite unit. Tsujimori et al. (2000) [41] reported ages of ca. 403-443 Ma from the meta-cumulate rocks of Unit II in the Oeyama body, and Nishimura and Shibata (1989) [42] reported ages of ca. 444-469 Ma from the Wakasa body. On the other hand, fine-grained hornblende gabbro from the Ashidachi body yielded a K-Ar age of ca. $343 \mathrm{Ma}$ [43]. The K-Ar ages are considered to have been affected by secondary metamorphism after the accretion of the ophiolite unit [8].
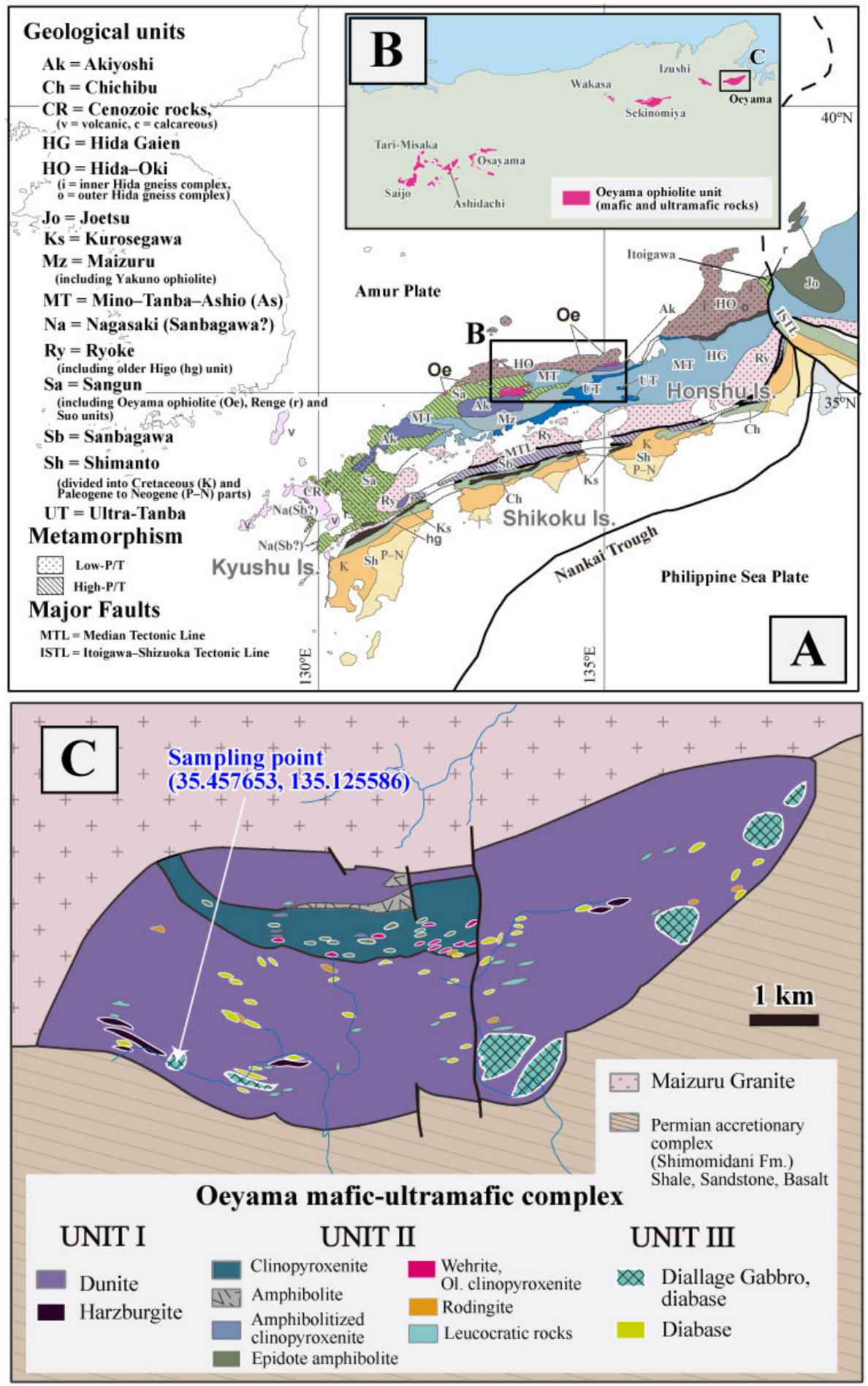

Figure 1. Geological map of studied area with sample locality. (A) Geotectonic map of SW Japan modified after [7]. (B) Distribution of major bodies of the Oeyama ophiolite unit. (C) Geological map of the Ooeyama mafic-ultramafic complex modified after Kurokawa (1985) [39]. 
Jadeitite blocks have been reported from the serpentinite mélange between the Oeyama ophiolite unit and the Sangun metamorphic belt in the Sekinomiya, Wakasa, and Osayama areas, which indicate subduction-related high P/T-type metamorphism, which occurred along the proto-Japan arc [42,44-46]. These jadeitites contain relatively large grains of zircon up to several millimeters in size and are dated at ca. 530-500 Ma [36,47]. Kimura and Hayasaka (2019) [8] suggested that the protolith of the jadeitite was the oceanic crust equivalent of the Oeyama ophiolite unit based on the similarity of their age and geochemical signature. Additionally, in the Itoigawa area, jadeitites occur in the serpentinite mélange of the Range Belt, and zircons from them have been dated at ca. 520-500 Ma [14,47,48].

\section{Materials and Methods}

\subsection{Sample}

The analyzed sample was collected from an outcrop located in the southern part of the Oeyama mafic-ultramafic unit (Figure 1C). The collected gabbroic rock sample was composed of the main gabbro part (sample number: OER-01) and vein of the anorthositic part (sample number: OER-02). The main part of the gabbro was mainly composed of plagioclase and clinopyroxene (Figure 2). Clinopyroxene showed well-developed cleavage. Relatively fresh plagioclase showed lamellar twinning, and the other grains were saussuritized. The vein part was composed mainly of coarse grains of saussuritized plagioclase up to $2 \mathrm{~cm}$ in size. Heavy mineral grains were separated from each sample at JAMSTEC (Yokosuka, Japan). Very few zircon samples were recovered from the main gabbro part (OER-01) through heavy mineral separation. On the other hand, over 100 grains of zircon were recovered from $300 \mathrm{~g}$ of the OER-02 sample through heavy mineral separation. Representative CL images of the analyzed zircon grains in the form of subhedral or anhedral shapes and faint oscillatory or sector zoning structures are shown in Figure 2D.

\section{2. $\mathrm{U}-\mathrm{Pb}$ Dating}

Zircon U-Pb dating was carried out by a Nu Plasma II (Nu instruments, Wrexham, UK) multiple-collector ICP-MS coupled to multiple-spot femtosecond laser ablation system (Jupiter Solid Nebulizer, ST Japan, Tokyo, Japan) installed at the Geochemical Research Center, The University of Tokyo (Tokyo, Japan). The wavelength of the laser is $257 \mathrm{~nm}$ (CARBIDE, Light Conversion, Lithuania). Laser ablation was conducted by a laser pit size of $8 \mu \mathrm{m}$ in diameter with a repetition rate of $1 \mathrm{kHz}$ and fluence of $4 \mathrm{~J} / \mathrm{cm}^{2}$. In this study, a square shaped ablation area $(20 \mu \mathrm{m} \times 20 \mu \mathrm{m})$ was ablated for ca. $5 \mathrm{~s}$ using a high-speed laser scanning achieved by the galvanometric scanner $[49,50]$. For carrier gas, $0.6 \mathrm{~L} / \mathrm{min}$ of He gas and $0.8 \mathrm{~L} / \mathrm{min}$ Ar make-up gas were combined outside the ablation cell. The mass spectrometer was equipped with six ion counters for the simultaneous measurement of ${ }^{202} \mathrm{Hg},{ }^{204} \mathrm{Hg}+{ }^{204} \mathrm{~Pb},{ }^{206} \mathrm{~Pb},{ }^{207} \mathrm{~Pb},{ }^{208} \mathrm{~Pb}$, and ${ }^{235} \mathrm{U}$, as described in Obayashi et al. (2017) [51], Hattori et al. (2017) [52], and Sawaki et al. (2020) [53]. The sample-standard bracketing technique was adopted to evaluate the instrumental drift and analytical uncertainty. As primary standards, NIST SRM612 and GJ-1 gem-quality zircon were used [54,55]. All analytical sessions were bracketed by three spot analyses of NIST SRM 612 and GJ-1 zircon, respectively, and included in total 15 spot analyses of unknown samples and secondary standards. Analytical uncertainties were combined with counting statistics of signal intensities, and the reproducibility of the standard analyses was added in quadrature. During the analytical sessions, we measured the ${ }^{206} \mathrm{~Pb} /{ }^{238} \mathrm{U}$ age of the OD-3 zircon to evaluate the reliability of the resulting age data [56]. The analyses of the secondary standards exhibited weighted mean ${ }^{206} \mathrm{~Pb} /{ }^{238} \mathrm{U}$ age of $32.7 \pm 0.2 \mathrm{Ma}(n=28)$, which is coincident with previously reported values within the analytical error. 

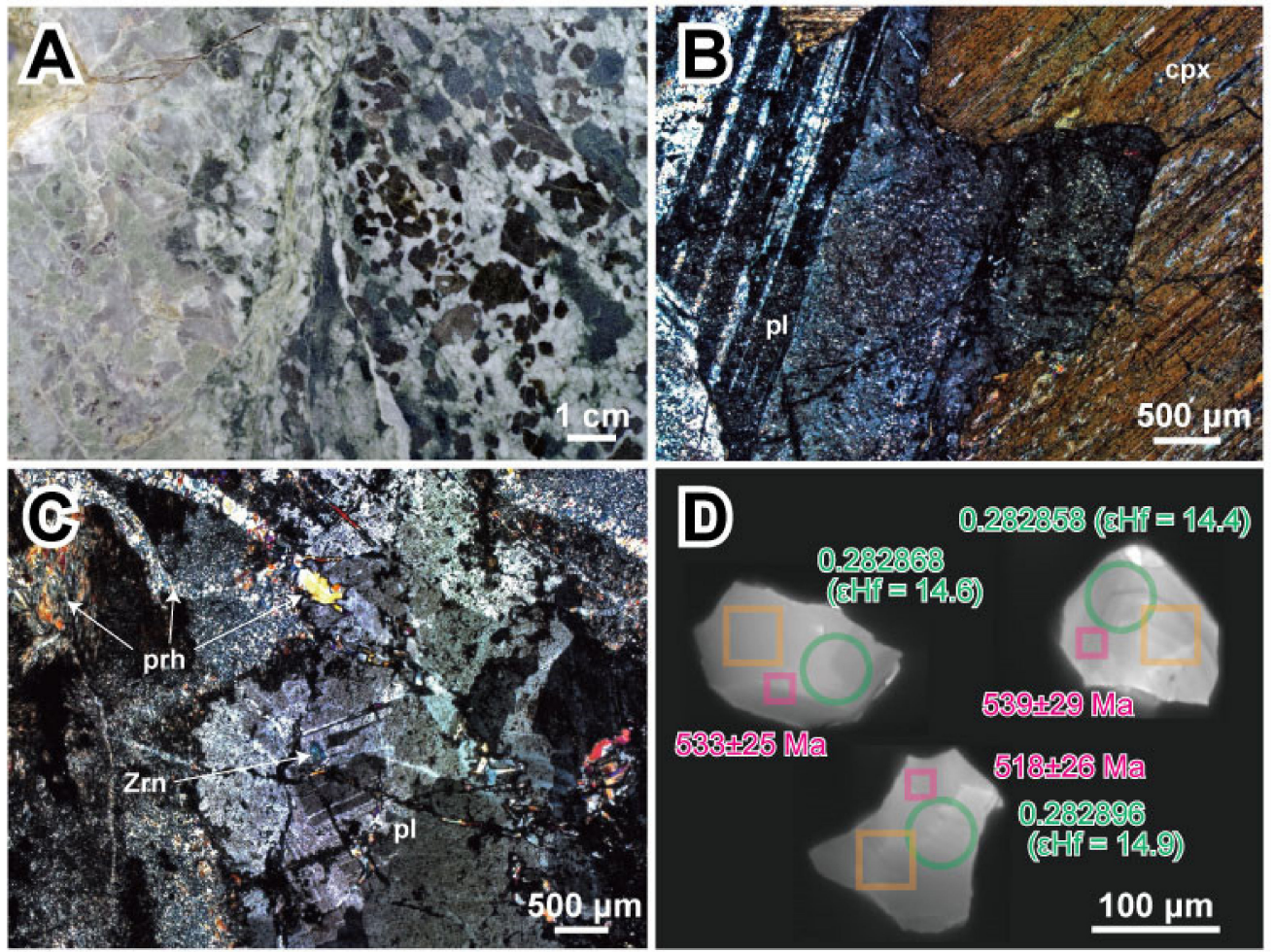

Figure 2. Sample photos. (A) Photo of the cut section of the rock sample. The right side is the main gabbro part (sample number OER-01), and the left side is the vein of the anorthositic part (OER-02). (B) Thin sectional view of the OER-01, which is mainly composed of diallage CPX and plagioclase. (C) Thin sectional view of the OER-02 mainly consists of saussuritized plagioclase and prehnite. (D) Cathodoluminescence images of zircon grains from the sample OER-02. Pink squares show analytical spots of U-Pb dating, whereas green circles show those of Lu-Hf isotopic analysis and orange squares show trace element analysis. $\mathrm{pl}=$ plagioclase, $\mathrm{cpx}=$ clinopyroxene, $\mathrm{prh}=$ prehnite, $\mathrm{Zrn}=$ zircon .

\section{3. $\mathrm{Lu}-\mathrm{Hf}$ Isotopic Analysis}

Zircon Lu-Hf isotopic analysis was performed on a Neptune-plus multiple collector (MC)-ICP-MS (Thermo Fisher Scientific, Waltham, MA, USA) coupled to a Photon Machines Analyte G2 excimer laser system installed at JAEA (Gifu, Japan). The data were acquired from ablation pits of $50 \mu \mathrm{m}$ diameter with a laser repetition rate of $15 \mathrm{~Hz}, 20 \mathrm{~s}$ ablation time, and fluence of $8.00 \mathrm{~J} / \mathrm{cm}^{2}$. To increase the signal intensity, $4.0 \mathrm{~mL} / \mathrm{min}$ of $\mathrm{N}_{2}$ gas was mixed with $\mathrm{Ar}$ gas as the carrier gas (e.g., [57,58]). Isotopes of ${ }^{171} \mathrm{Yb},{ }^{173} \mathrm{Yb}$, ${ }^{175} \mathrm{Lu},{ }^{176}(\mathrm{Hf}+\mathrm{Yb}+\mathrm{Lu}),{ }^{177} \mathrm{Hf},{ }^{178} \mathrm{Hf}$, and ${ }^{179} \mathrm{Hf}$ were monitored using seven Faraday cups. The contribution of the isobaric interferences on ${ }^{176} \mathrm{Hf}$ by ${ }^{176} \mathrm{Yb}$ and ${ }^{176} \mathrm{Lu}$ was corrected based on the signal intensities of ${ }^{173} \mathrm{Yb}$ and ${ }^{175} \mathrm{Lu}$ by normalizing the ${ }^{76} \mathrm{Yb} /{ }^{173} \mathrm{Yb}$ and ${ }^{176} \mathrm{Lu} /{ }^{175} \mathrm{Lu}$ ratios of 0.78696 [59] and 0.026549 [60], respectively. After the correction of the isobaric interferences, the mass discrimination effect on Hf isotopes was corrected by the measured ${ }^{176} \mathrm{Hf} /{ }^{177} \mathrm{Hf}$ ratio using the exponential law [61]. The mass bias factor for $\mathrm{Yb}$ was calculated by normalizing the measured ${ }^{173} \mathrm{Yb} /{ }^{171} \mathrm{Yb}$ to 1.12346 [59], whereas those for $\mathrm{Hf}$ and Lu were calculated by normalizing the measured ${ }^{179} \mathrm{Hf} /{ }^{177} \mathrm{Hf}$ to 0.7325 [62]. Mud Tank zircon $\left({ }^{178} \mathrm{Hf} /{ }^{177} \mathrm{Hf}=1.467168\right.$ and ${ }^{176} \mathrm{Hf} /{ }^{177} \mathrm{Hf}=0.282523$ [63] $)$ were used to correct for mass bias. During the sample analysis, zircon standard materials of 91500 [64] and TEMORA2 [65] were analyzed for isotope quality control. The reference values for the ${ }^{176} \mathrm{Hf} /{ }^{177} \mathrm{Hf}$ isotopes of the 91500 and TEMORA2 were $0.282306 \pm 0.00008$ and $0.282686 \pm 0.00008$, respectively [66]. The obtained means ${ }^{176} \mathrm{Hf} /{ }^{177} \mathrm{Hf}$ of 91500 and TEMORA2 were $0.282317 \pm 0.000005(2 \mathrm{SD}, n=8)$ and $0.282685 \pm 0.000014(2 \mathrm{SD}, n=8)$, respectively. These results are consistent with the above reference values. 


\subsection{Zircon Trace Element Analysis}

Zircon trace element analysis was performed by using an $\mathrm{ICAP}$ TQ tandem quadrupole ICPMS (Thermo Fisher Scientific, USA) combined with the multiple-spot laser ablation system used for the $\mathrm{U}-\mathrm{Pb}$ dating described above. Analytical spots of trace elements geochemistry were selected to be next to those of $\mathrm{U}-\mathrm{Pb}$ age dating and $\mathrm{Lu}-\mathrm{Hf}$ isotope analysis. A spot size of $42 \mu \mathrm{m} \times 42 \mu \mathrm{m}$ square area was ablated for each analysis by scanning laser beam of ca. $10 \mu \mathrm{m}$ in diameter with repetition rate of $400 \mathrm{~Hz}$ and fluence of $2.0-2.5 \mathrm{~J} / \mathrm{cm}^{2}$. Fluence of carrier gas was the same as that of the U-Pb dating. To remove interference from polyatomic ions (e.g., ${ }^{29} \mathrm{Si}^{16} \mathrm{O}^{+}$ to $\left.{ }^{45} \mathrm{Sc}^{+}\right), 0.25 \mathrm{~mL} / \mathrm{min}$ of $\mathrm{O}_{2}$ gas was flowed into a collision/reaction cell between the tandem quadrupole mass spectrometer. In this study, signal intensities of total 22 isotopes or oxide ions, ${ }^{28} \mathrm{Si}^{16} \mathrm{O},{ }^{45} \mathrm{Sc}^{16} \mathrm{O},{ }^{89} \mathrm{Y}^{16} \mathrm{O},{ }^{93} \mathrm{Nb}^{16} \mathrm{O},{ }^{139} \mathrm{La}^{16} \mathrm{O},{ }^{140} \mathrm{Ce}^{16} \mathrm{O},{ }^{141} \mathrm{Pr}^{16} \mathrm{O},{ }^{146} \mathrm{Nd}^{16} \mathrm{O},{ }^{147} \mathrm{Sm}^{16} \mathrm{O}$, ${ }^{153} \mathrm{Eu},{ }^{157} \mathrm{Gd}^{16} \mathrm{O},{ }^{159} \mathrm{~Tb}^{16} \mathrm{O},{ }^{163} \mathrm{Dy}^{16} \mathrm{O},{ }^{165} \mathrm{Ho}^{16} \mathrm{O},{ }^{166} \mathrm{Er}^{16} \mathrm{O},{ }^{169} \mathrm{Tm}^{16} \mathrm{O},{ }^{172} \mathrm{Yb},{ }^{175} \mathrm{Lu}^{16} \mathrm{O},{ }^{178} \mathrm{Hf}^{16} \mathrm{O}$, ${ }^{181} \mathrm{Ta}^{16} \mathrm{O}_{2},{ }^{232} \mathrm{Th}^{16} \mathrm{O}$, and ${ }^{238} \mathrm{U}^{16} \mathrm{O}$, were monitored.

The primary calibration standard and internal standard element, NIST SRM612 and ${ }^{28} \mathrm{Si}^{16} \mathrm{O}$, were used, respectively. The preferred average of the measured elements in NIST SRM612 by [67] was used for the calculation of the abundance values. The concentration of the internal standard element in the analyzed zircon grains was assumed to be the same as that of the 91,500 zircon standard (i.e., $15.28 \mathrm{wt} \%$, [64]). The mean and standard deviation of the measured ratios among each of the six primary standard data bracketing unknown sample groups were applied to calculate trace element concentrations. The results of 91,500 standard zircon analyses as a secondary standard are summarized in Supplementary Table S1, which showed good agreement with the literature values [64].

\section{Results}

The results of the zircon analyses are summarized in Supplementary Table S2. Zircon grains from OER-01 exhibited slightly discordant $\mathrm{U}-\mathrm{Pb}$ ages with ${ }^{206} \mathrm{~Pb} /{ }^{238} \mathrm{U}$ ages of $540-590 \mathrm{Ma}$, which was possibly affected by common $\mathrm{Pb}$ contamination. Thirty-six zircon grains out of the analyzed 50 grains separated from sample OER-02 were plotted on the concordia line (Figure 3A). No clear relationship between the $\mathrm{U}$ and $\mathrm{Pb}$ dating results and internal crystal structures was observed. The weighted mean ${ }^{206} \mathrm{~Pb} /{ }^{238} \mathrm{U}$ age of concordant data was $544 \pm 4 \mathrm{Ma}$ (2-sigma level, MSWD = 1.77; Figure 3B), and the weighted mean ${ }^{207} \mathrm{~Pb} /{ }^{235} \mathrm{U}$ age was $540 \pm 3 \mathrm{Ma}$ (2-sigma level, MSWD = 1.46). These zircons exhibited relatively high Hf content $(>20,000 \mathrm{ppm})$, low $\mathrm{U} / \mathrm{Yb}$ and $\mathrm{Nb} / \mathrm{Yb}$ ratios, medium $\mathrm{Y}$ concentrations, and $\mathrm{Sc} / \mathrm{Yb}$ ratios (Figure $4 \mathrm{~A}-\mathrm{E}$ ). The chondrite-normalized rare earth element (REE) patterns of the zircon grains showed enrichment of heavy REE (HREE), positive Ce anomalies, and negative Eu anomalies (Figure 4F). The Lu-Hf isotopic analysis showed an initial ${ }^{176} \mathrm{Hf} /{ }^{177} \mathrm{Hf}$ ratio between 0.282834 and 0.282913 and initial $\varepsilon$ Hf values between 13.4 and 16.5. These values were slightly higher than those of the depleted mantle (DM) curve (Figure 5). However, no clear relationship between the Hf isotopic ratio and trace element concentration or ratio was observed (Figure 6).
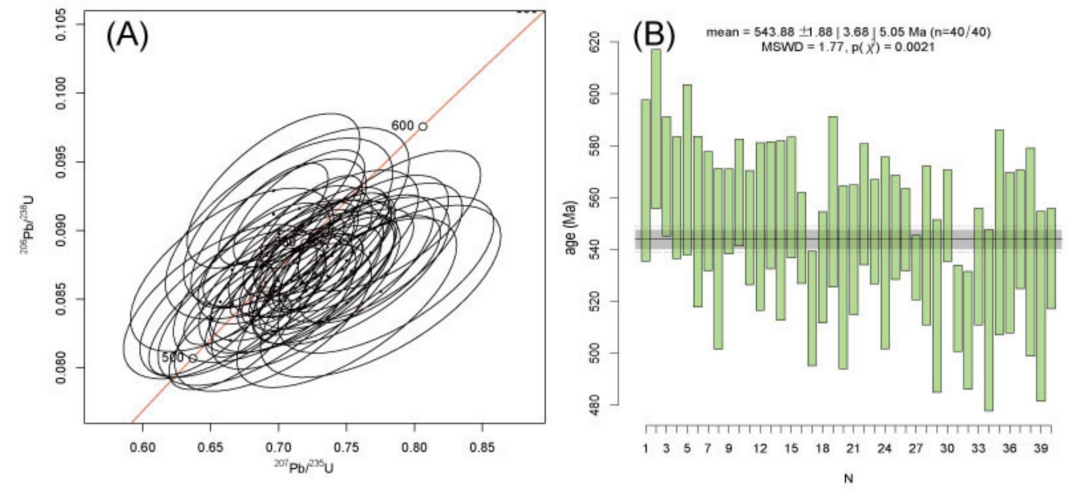

Figure 3. Results of $\mathrm{U}-\mathrm{Pb}$ dating. (A) Concordia diagram of analytical results of zircon from the sample OER-02. (B) Weighted mean of ${ }^{238} \mathrm{U}-{ }^{206} \mathrm{~Pb}$ ages selected data which are plotted on the concordia line in A. All plots were generated by using IsoplotR [68]. 
(A) $\mathrm{U} / \mathrm{Yb}$ vs Hf

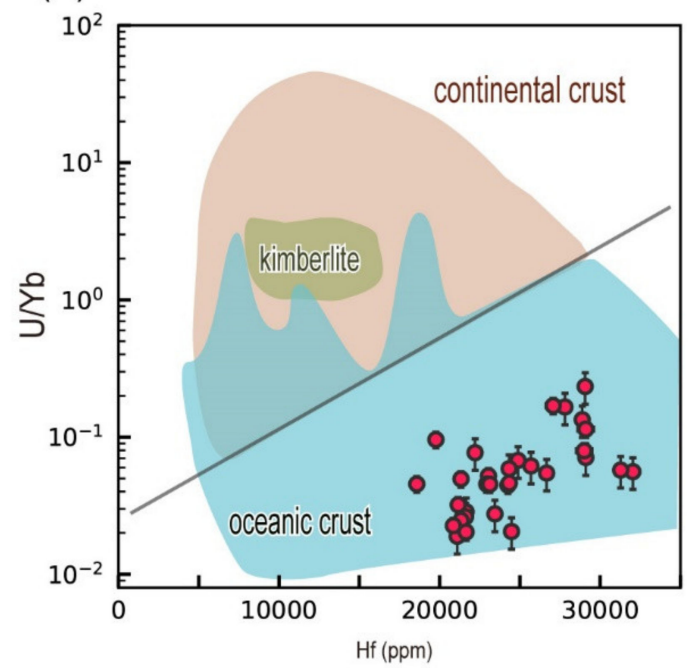

(C) $\mathrm{Nb} / \mathrm{Yb}$ vs U/Yb

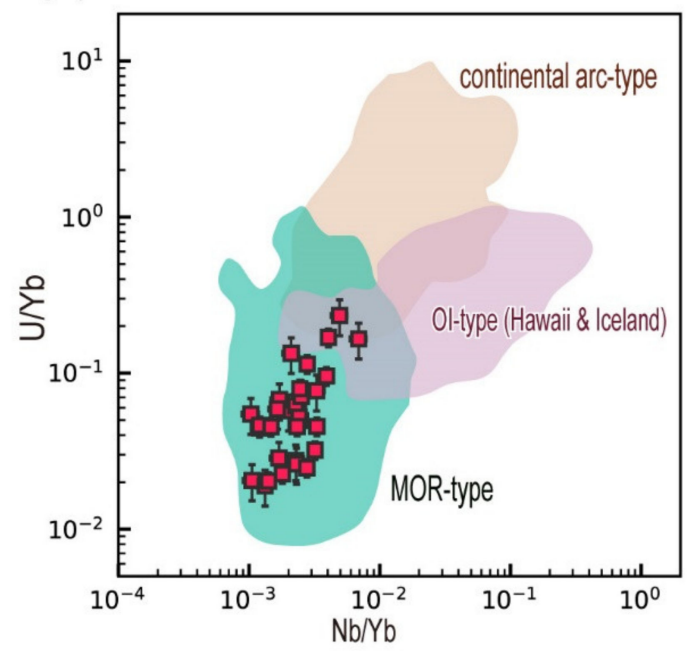

(E) $\mathrm{Sc} / \mathrm{Yb}$ vs U/Yb

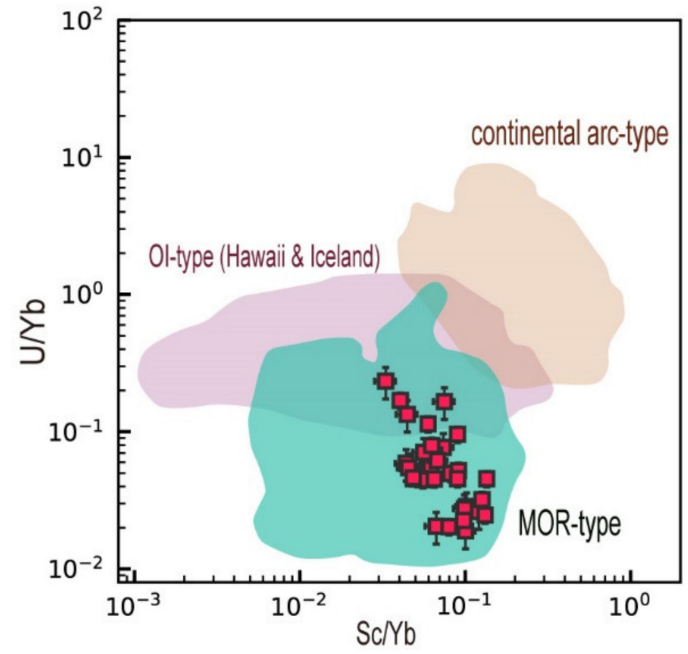

(B) $U / Y b$ vs $Y$

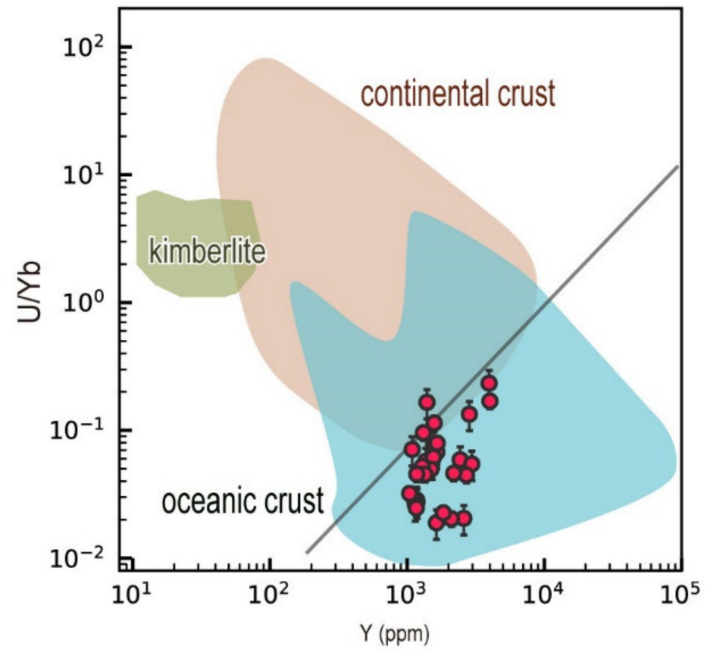

(D) $\mathrm{Nb} / \mathrm{Yb}$ vs $\mathrm{Sc} / \mathrm{Yb}$

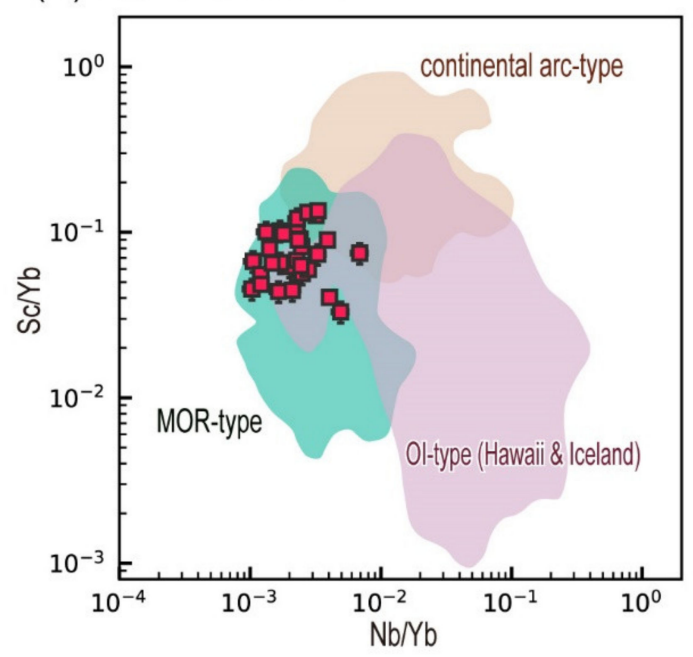

(F) chondrite normalized REE pattern

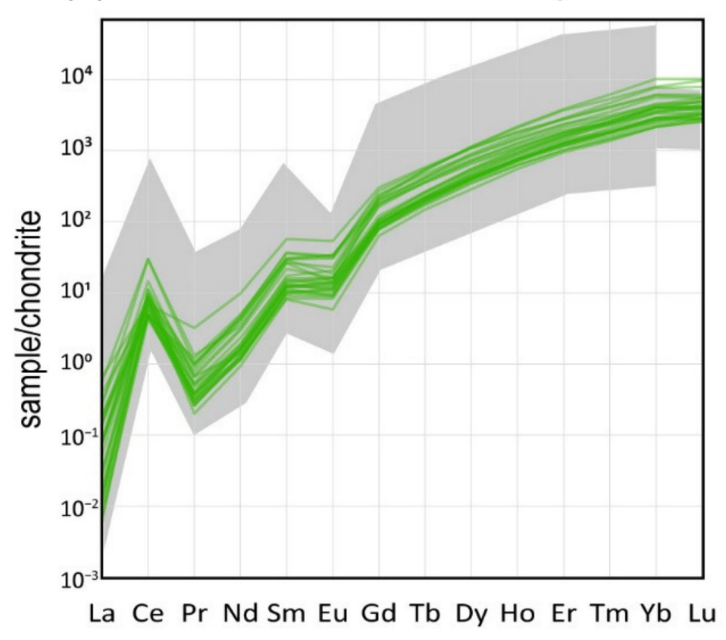

Figure 4. Trace element analysis of zircon from the sample OER-02. (A) Hf concentration vs. U/Yb ratio, (B) Y concentration vs. U/Yb ratio [27], (C) $\mathrm{Nb} / \mathrm{Yb}$ ratio vs. U/Yb ratio, (D) $\mathrm{Nb} / \mathrm{Yb}$ ratio vs. $\mathrm{Sc} / \mathrm{Yb}$ ratio, (E) $\mathrm{Sc} / \mathrm{Yb}$ ratio vs. $\mathrm{U} / \mathrm{Yb}$ ratio [26], (F) chondrite-normalized rare earth element pattern. Gray-filled areas indicate the composition of typical zircons from oceanic crustal rocks [27]. 


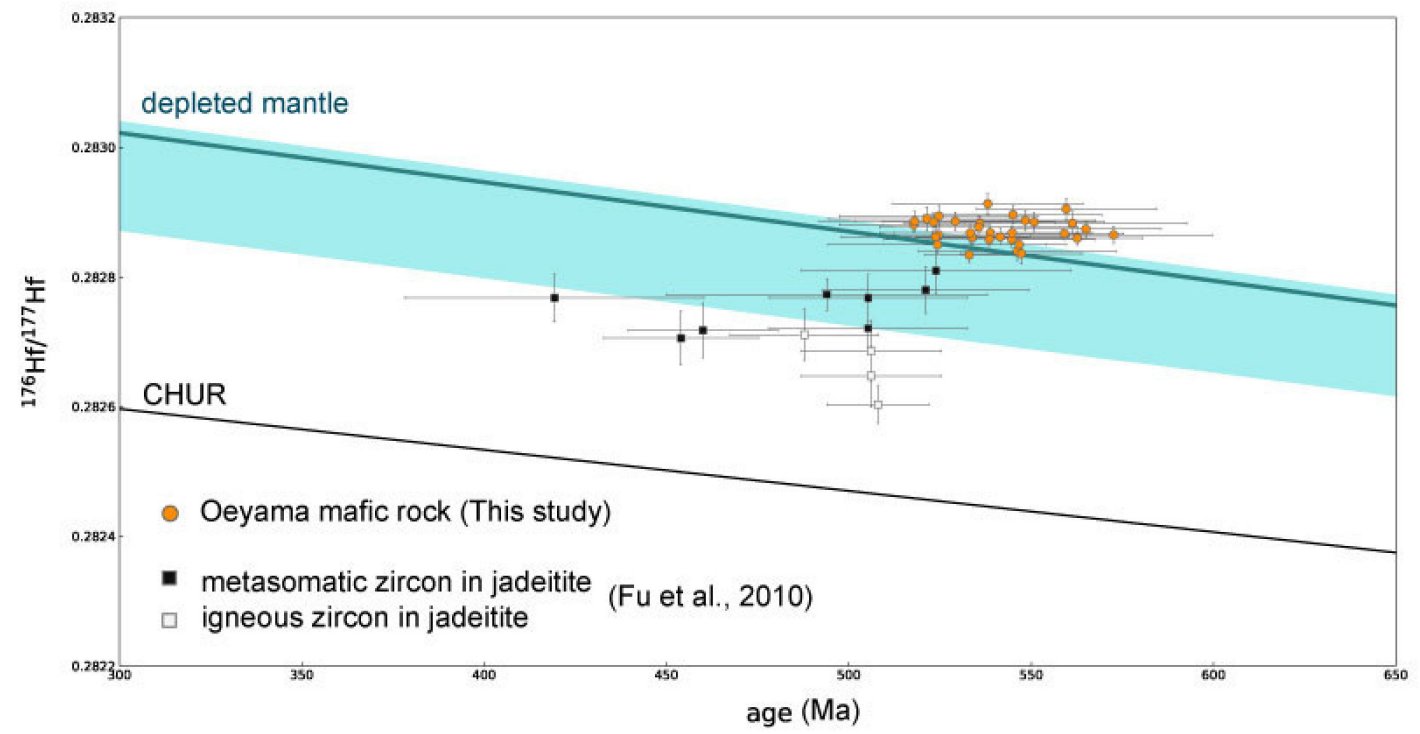

Figure 5. Zircon $\mathrm{U}-\mathrm{Pb}$ age versus initial $\mathrm{Hf}$ isotopic ratio diagram for the present results of $\mathrm{Lu}-\mathrm{Hf}$ isotope analysis of the Oeyama mafic-ultramafic complex and previously reported data for zircons in jadeitite from the Osayama area by [34]. Depleted mantle domain shown in green and CHUR (Chondritic uniform reservoir) curve of a black curve were defined by $[69,70]$.
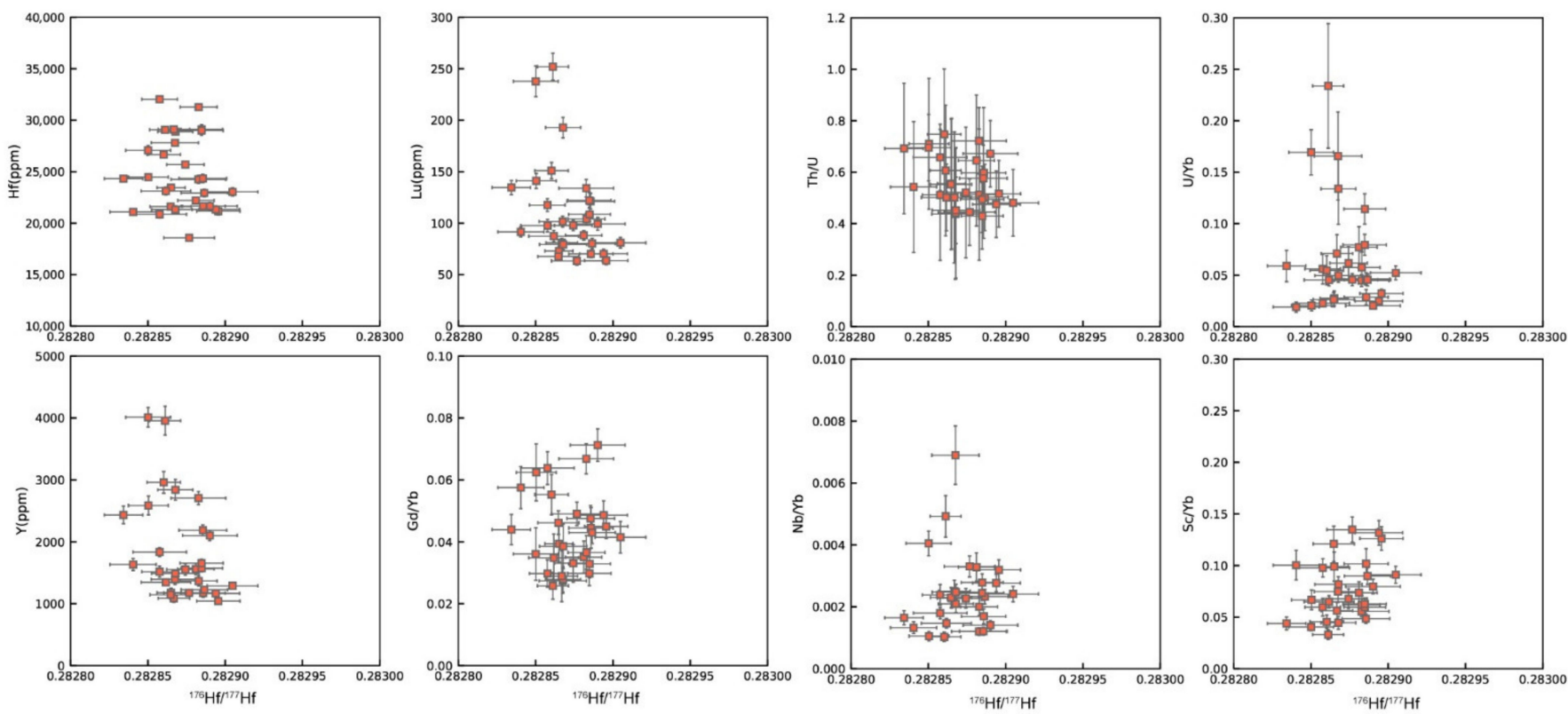

Figure 6. Plots of initial ${ }^{176} \mathrm{Hf} /{ }^{177} \mathrm{Hf}$ isotopic ratio versus trace element concentration or trace element ratio of zircons in sample OER-02 (anorthositic vein in gabbroic rock) from the Oeyama mafic-ultramafic complex.

\section{Discussion}

\subsection{Igneous Age of Mafic Rocks in the Oeyama Ophiolite}

The analyzed zircons from sample OER-02 exhibiting concordant $\mathrm{U}-\mathrm{Pb}$ ages showed Th/U ratios higher than 0.1, a common chemical feature of typical igneous zircons (e.g., [71,72]). In addition, the obtained REE pattern with positive Ce anomalies, negative Eu anomalies, and HREE enrichment is also typical for igneous zircons [72]. Although the analyzed zircons do not show any clear internal zoning structure, zircons exhibiting such charac- 
teristics are often found in gabbroic rocks (e.g., [27]). Therefore, the weighted mean of the present zircon $\mathrm{U}-\mathrm{Pb}$ ages indicates the igneous age of the host mafic rocks. In the following discussion, a weighted mean ${ }^{206} \mathrm{~Pb} /{ }^{238} \mathrm{U}$ age of $544 \mathrm{Ma}$ is adopted as the igneous age. This igneous age is consistent with those previously reported in the Saijo unit [8]. This result confirms that the mafic rocks of the Oeyama ophiolite unit (i.e., Unit II according to Kurokawa (1985) [39]) was formed and accreted almost simultaneously along the plate subduction zone of the proto-Japan arc.

\subsection{Source Mantle of the Oeyama Ophiolite Unit}

In the discrimination diagrams of Grimes et al. $(2009 ; 2015)[26,27]$, the present data of trace element analyses are plotted on the oceanic crust domain or MOR-type domain (Figure 4). This result is consistent with previously reported trace element data for mafic rocks of the Saijo area by Kimura and Hayasaka (2019) [8]. These data confirm the east-west continuity of the Oeyama ophiolite unit, which had been formed from the depleted mantle source, such as mid-oceanic ridges.

The present result of the Lu-Hf isotopic analysis shows that the initial ${ }^{176} \mathrm{Hf} /{ }^{177} \mathrm{Hf}$ ratio is slightly higher than that of the depleted mantle at that time, indicating that the mafic rocks of the Oeyama ophiolite unit were derived from a strongly depleted mantle domain. This is consistent with the trace element analysis of the zircons described above. This Hf isotopic result is also consistent with whole-rock $\mathrm{Nd}$ isotopic analysis by Kimura and Hayasaka (2019) [8], who showed that the initial Nd ratio for the five samples ranged between 0.512169 and 0.512382 , namely initial $\varepsilon N d$ between 7 and 8 . Furthermore, the present ${ }^{176} \mathrm{Hf} /{ }^{177} \mathrm{Hf}$ ratio is still slightly higher than the depleted mantle at the U-Pb age, even after considering the diversity of the current mid-oceanic ridge basalt (MORB) source mantle and the initiation of the differentiation of the DM. Examples with Hf isotope ratios slightly higher than the DM range exist in various parts of the world, and their tectonic settings are also diverse. Examples of similar ages include ophiolites with the oceanic crustal origin [20], intra-plate magmatism [73], and subduction orogenic components [74-76]. Local isotopic variations may differ from global mantle differentiation. It has been remarked that the presence of garnet in the residual material during partial melting can increase the Hf isotopic ratio [77]. In the present study, however, the trace element signature and Hf isotopic ratio do not show any relationship, and we do not have any evidence of garnet in the restites of the Oeyama ophiolite unit. Another possible explanation for the data is that the Hf isotopic values were inherited from an ultra-depleted mantle domain which had formed through extremely active igneous activity in the Archean or Hadean. Several studies have reported Hf isotopic values higher than the normal depleted mantle domain through zircon in-site analysis and whole rock analysis of from early Archean rocks [78-81]. Such highly depleted mantle domains may have existed in the Rodinia continent as cratonic keels and participated in the partial melting during the formation of the oceanic crust of the Oeyama ophiolite unit. Even though the reason why the present zircons show slightly higher than the depleted mantle domain is still not conclusive, that may reflect the formation environment of the Oeyama ophiolite unit.

\subsection{Comparison with Associated Jadeitite and Implication for Paleogeographic Reconstruction}

The jadeitite associated with the Oeyama ophiolite unit yielded zircon $\mathrm{U}-\mathrm{Pb}$ ages of ca. 530-500 Ma [36,47]. Fu et al. (2010) [34] further reported two texturally contrasting groups of zircons from jadeitite in the Osayama area by cathodoluminescence observation, that is, igneous and hydrothermal types, and carried out Lu-Hf and oxygen isotope analyses. The igneous type zircons with faint oscillatory or patchy zoning show $\delta^{18} \mathrm{O}=5.0 \pm 0.4 \%$ (2SD, Vienna Standard Mean Ocean Water (VSMOW)), whereas hydrothermal-type zircons with featureless or weak zoning show $\delta^{18} \mathrm{O}=3.8 \pm 0.6 \%$, which supports the typing based on the CL images. Both types of zircons show Hf isotopic ratios between CHUR and depleted mantle, and those of the igneous type zircons are lower than the hydrothermal type. They regarded that igneous-type zircons were inherited from protolith of pre-existing 
igneous rocks or subducted sediments, and the hydrothermal-type ones are precipitate from metasomatic fluid. They further interpreted that the high $\mathrm{Hf}$ isotopic values of the hydrothermal-type zircons are derived from rocks generated from depleted mantle sources.

The present zircon Hf isotopic analysis of the Oeyama ophiolite unit exhibited higher values than both types of zircons in the jadeitite. This result indicates that the igneous-type zircons in the jadeitite have a different origin from the mafic rocks of the Oeyama ophiolite unit. On the contrary, the Hf isotopic values of the hydrothermal-type zircon can be well explained by mixing of the igneous-type zircons in the jadeitite and the present ones in the Oeyama ophiolite unit. The mafic rocks in the oceanic crust or related mantle material probably contributed to produce the metasomatic-type zircons in the jadeitite. We note that the igneous-type zircons in Fu et al. (2010) may indicate a younger age than the original igneous age due to $\mathrm{Pb}$-loss during the metasomatism, even though their $\mathrm{Hf}$ and $\mathrm{O}$ isotopic values are less affected by the metasomatism. The present result requires another source for the jadeitite, which had $\mathrm{U}-\mathrm{Pb}$ ages older than ca. $530 \mathrm{Ma}$ and a Hf isotopic signature lower than 0.2826 . There are two possible explanations for this jadeitite source. First, the subduction initiation involved some older crustal material in the Rodinia continent with Hf isotopic ratio lower than those of zircons in the jadeitite (Figure 7A). In this case, we need to assume that the igneous-type zircons were originally older than $530 \mathrm{Ma}$ and secondarily lost the $\mathrm{U}-\mathrm{Pb}$ ages during the metasomatism. The other is the subduction involved arc crusts which had Hf isotopic composition lower than 0.2826 (Figure 7B). This model requires that the subduction initiation along the proto-Japan region was older than 530 Ma previously envisaged, probably 600 Ma or older, enough to produce arc crust with such low Hf isotopic values. If we follow the model of oceanward subduction initiation described by Kumira and Hayasaka (2019) [8], the latter model is more probable and that suggests subduction initiation along the proto-Japan arc much older than $530 \mathrm{Ma}$. Nonetheless, we still do not have evidence to determine which model is correct at the time, and the relationship between ophiolite and jadeitite is probably the key to further revealing the details of subduction initiation.

A

B

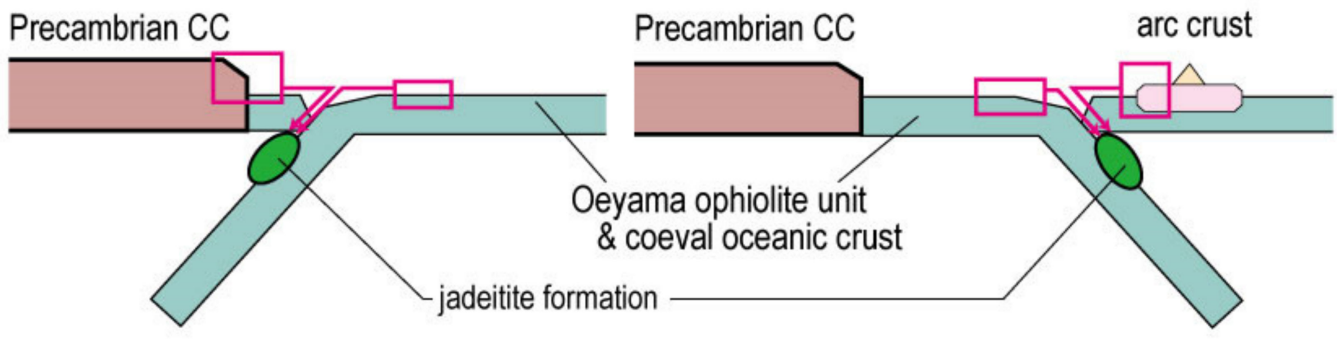

Figure 7. Two possible model to explain the present zircon Hf isotopic analysis for a gabbroic rock from the Oeyama ophiolite unit and that of the jadeitite associated with the ophiolite unit. (A) The initial subduction was landward and the jadeitite was formed from the Precambrian continental crust (CC) in the Rodinia fragments and the oceanic crust coeval to the Oeyama ophiolite unit. (B) The initial subduction was oceanward and started at $>$ ca. $600 \mathrm{Ma}$. The source of the jadeitite was a mixture of the oceanic crust coeval to the Oeyama ophiolite unit and the arc crust formed through the subduction.

\section{Conclusions}

The gabbroic rocks of the Oeyama mafic-ultramafic complex in southwest Japan were a fragment of ca. $544 \mathrm{Ma}$ oceanic crust. Trace element analysis of the zircons revealed that the host rock was derived from the mantle depleted of incompatible elements such as MORB. The present igneous age and geochemical features of the zircons are consistent with previous work for other parts of the Oeyama ophiolitic unit. Zircon Lu-Hf isotopic analysis also indicates that the gabbroic rock was derived from a depleted mantle domain like the MORB. The Hf isotopic signature is more depleted than those of the zircons in the jadeitite 
associated with the Oeyama ophiolite unit. This result may suggest that the subduction initiation along the proto-Japan arc was older than $530 \mathrm{Ma}$ as previously thought.

Supplementary Materials: The following are available online at https:/ / www.mdpi.com/article/ 10.3390/min12010107/s1. Supplementary Table S1: Analytical results of trace element content of 91500 standard zircon. Supplementary Table S2: Results of zircon U-Pb, Lu-Hf, and trace element analyses.

Author Contributions: Conceptualization, H.S.; investigation, H.S., S.N., and M.N.; Methodology, H.S., S.N., M.N., and T.H.; resources, H.S. and T.H.; writing-original draft preparation, H.S.; writingreview and editing, M.N., S.N., and T.H. All authors have read and agreed to the published version of the manuscript.

Funding: This work was supported by Japan Society of Promotion of Science (JSPS KAKENHI Grants-in-Aid for Scientific Research Grant No. 20K14571, 19K23458, and 19KK0092 to HS) from the Japanese Ministry of Education, Science, Sports, Technology, and Culture.

Data Availability Statement: The data presented in this study are available in Supplementary Tables S1 and S2.

Acknowledgments: We are grateful to A. Gomi (Itochu Mineral Resources Development Corp.) for providing us with natural zircon standard. We thank A. Hatakeyama (JAMSTEC) for helping with heavy mineral separation. The results of Lu-Hf analysis in this study are part of the establishment of Lu-Hf analysis of zircon that Nagata conducted as a Research Fellowship at JAEA. We thank T. Yokoyama, S. Kagami, and all the staff at the Tono Geoscience Center, JAEA.

Conflicts of Interest: The authors declare no conflict of interest.

\section{References}

1. Coleman, R.G. What Is an Ophiolite? In Ophiolites; Springer: Berlin, Heidelberg, 1977; Volume 12, pp. 1-7.

2. Furnes, H.; de Wit, M.; Dilek, Y. Four Billion Years of Ophiolites Reveal Secular Trends in Oceanic Crust Formation. Geosci. Front. 2014, 5, 571-603. [CrossRef]

3. Whattam, S.A.; Stern, R.J. The 'Subduction Initiation Rule': A Key for Linking Ophiolites, Intra-Oceanic Forearcs, and Subduction Initiation. Contrib. Mineral. Petrol. 2011, 162, 1031-1045. [CrossRef]

4. Isozaki, Y.; Aoki, K.; Nakama, T.; Yanai, S. New Insight into a Subduction-Related Orogen: A Reappraisal of the Geotectonic Framework and Evolution of the Japanese Islands. Gondwana Res. 2010, 18, 82-105. [CrossRef]

5. Isozaki, Y. A Visage of Early Paleozoic Japan: Geotectonic and Paleobiogeographical Significance of Greater South China. Isl. Arc 2019, 28, e12296. [CrossRef]

6. Wakita, K. Geology and Tectonics of Japanese Islands: A Review-The Key to Understanding the Geology of Asia. J. Asian Earth Sci. 2013, 72, 75-87. [CrossRef]

7. Wallis, S.R.; Yamaoka, K.; Mori, H.; Ishiwatari, A.; Miyazaki, K.; Ueda, H. The Basement Geology of Japan from A to Z. Isl. Arc 2020, 29. [CrossRef]

8. Kimura, K.; Hayasaka, Y. Zircon U-Pb Age and Nd Isotope Geochemistry of Latest Neoproterozoic to Early Paleozoic Oeyama Ophiolite: Evidence for Oldest MORB-Type Oceanic Crust in Japanese Accretionary System and Its Tectonic Implications. Lithos 2019, 342-343, 345-360. [CrossRef]

9. Bose, S.; Das, K.; Torimoto, J.; Arima, M.; Dunkley, D.J. Evolution of the Chilka Lake Granulite Complex, Northern Eastern Ghats Belt, India: First Evidence of-780 Ma Decompression of the Deep Crust and Its Implication on the India-Antarctica Correlation. Lithos 2016, 263, 161-189. [CrossRef]

10. Meert, J.G.; Torsvik, T.H. The Making and Unmaking of a Supercontinent: Rodinia Revisited. Tectonophysics 2003, 375, 261-288. [CrossRef]

11. Isozaki, Y.; Ehiro, M.; Nakahata, H.; Aoki, K.; Sakata, S.; Hirata, T. Cambrian Plutonism in Northeast Japan and Its Significance for the Earliest Arc-Trench System of Proto-Japan: New U-Pb Zircon Ages of the Oldest Granitoids in the Kitakami and Ou Mountains. J. Asian Earth Sci. 2015, 108, 136-149. [CrossRef]

12. Tagiri, M.; Dunkley, D.J.; Adahi, T.; Hiroi, Y.; Fanning, C.M. SHRIMP Dating of Magmatism in the Hitachi Metamorphic Terrane, Abukuma Belt, Japan: Evidence for a Cambrian Volcanic Arc. Isl. Arc 2011, 20, 259-279. [CrossRef]

13. Sakashima, T.; Terada, K.; Takeshita, T.; Sano, Y. Large-Scale Displacement along the Median Tectonic Line, Japan: Evidence from SHRIMP Zircon U-Pb Dating of Granites and Gneisses from the South Kitakami and Paleo-Ryoke Belts. J. Asian Earth Sci. 2003, 21, 1019-1039. [CrossRef]

14. Kunugiza, K.; Goto, A. Juvenile Japan: Hydrothermal Activity of the Hida-Gaien Belt Indicating Initiation of Subduction of Proto-Pacific Plate in ca. 520 Ma. Chigaku Zasshi (J. Geogr.) 2010, 119, 279-293. [CrossRef] 
15. Tsujimori, T.; Harlow, G.E. Jadeitite (Jadeite Jade) from Japan: History, Characteristics, and Perspectives. J. Mineral. Petrol. Sci. 2017, 112, 184-196. [CrossRef]

16. Dilek, Y.; Thy, P. Age and Petrogenesis of Plagiogranite Intrusions in the Ankara Melange, Central Turkey. Isl. Arc 2006, 15, 44-57. [CrossRef]

17. Samson, S.D.; Inglis, J.D.; D’Lemos, R.S.; Admou, H.; Blichert-Toft, J.; Hefferan, K. Geochronological, Geochemical, and Nd-Hf Isotopic Constraints on the Origin of Neoproterozoic Plagiogranites in the Tasriwine Ophiolite, Anti-Atlas Orogen, Morocco. Precambrian Res. 2004, 135, 133-147. [CrossRef]

18. Rioux, M.; Bowring, S.; Kelemen, P.; Gordon, S.; Miller, R.; Dudás, F. Tectonic Development of the Samail Ophiolite: High-Precision U-Pb Zircon Geochronology and Sm-Nd Isotopic Constraints on Crustal Growth and Emplacement. J. Geophys. Res. Solid Earth 2013, 118, 2085-2101. [CrossRef]

19. Zhang, C.-L.; Santosh, M.; Zou, H.-B.; Li, H.-K.; Huang, W.-C. The Fuchuan Ophiolite in Jiangnan Orogen: Geochemistry, Zircon U-Pb Geochronology, Hf Isotope and Implications for the Neoproterozoic Assembly of South China. Lithos 2013, 179, $263-274$. [CrossRef]

20. Arena, K.R.; Hartmann, L.A.; Lana, C. Evolution of Neoproterozoic Ophiolites from the Southern Brasiliano Orogen Revealed by Zircon U-Pb-Hf Isotopes and Geochemistry. Precambrian Res. 2016, 285, 299-314. [CrossRef]

21. Lissenberg, C.J.; Rioux, M.; Shimizu, N.; Bowring, S.A.; Mével, C. Zircon Dating of Oceanic Crustal Accretion. Science 2009, 323, 1048-1050. [CrossRef]

22. Karaoglan, F.; Parlak, O.; Klotzli, U.; Thoni, M.; Koller, F. U-Pb and Sm-Nd Geochronology of the K1zıldağ (Hatay, Turkey) Ophiolite: Implications for the Timing and Duration of Suprasubduction Zone Type Oceanic Crust Formation in the Southern Neotethys. Geol. Mag. 2013, 150, 283-299. [CrossRef]

23. Griffin, W.L.; Belousova, E.A.; Shee, S.R.; Pearson, N.J.; O'Reilly, S.Y. Archean Crustal Evolution in the Northern Yilgarn Craton: $\mathrm{U}-\mathrm{Pb}$ and Hf-Isotope Evidence from Detrital Zircons. Precambrian Res. 2004, 131, 231-282. [CrossRef]

24. Knudsen, T.-L.; Griffin, W.; Hartz, E.; Andresen, A.; Jackson, S. In-Situ Hafnium and Lead Isotope Analyses of Detrital Zircons from the Devonian Sedimentary Basin of NE Greenland: A Record of Repeated Crustal Reworking. Contrib. Mineral. Petrol. 2001, 141, 83-94. [CrossRef]

25. Thirlwall, M.F.; Walder, A.J. In Situ Hafnium Isotope Ratio Analysis of Zircon by Inductively Coupled Plasma Multiple Collector Mass Spectrometry. Chem. Geol. 1995, 122, 241-247. [CrossRef]

26. Grimes, C.B.; Wooden, J.L.; Cheadle, M.J.; John, B.E. "Fingerprinting” Tectono-Magmatic Provenance Using Trace Elements in Igneous Zircon. Contrib. Mineral. Petrol. 2015, 170, 1-26. [CrossRef]

27. Grimes, C.B.; John, B.E.; Cheadle, M.J.; Mazdab, F.K.; Wooden, J.L.; Swapp, S.; Schwartz, J.J. On the Occurrence, Trace Element Geochemistry, and Crystallization History of Zircon from in Situ Ocean Lithosphere. Contrib. Mineral. Petrol. 2009, 158, 757-783. [CrossRef]

28. Grimes, C.B.; John, B.E.; Kelemen, P.B.; Mazdab, F.K.; Wooden, J.L.; Cheadle, M.J.; Hanghøj, K.; Schwartz, J.J. Trace Element Chemistry of Zircons from Oceanic Crust: A Method for Distinguishing Detrital Zircon Provenance. Geology 2007, 35, 643-646. [CrossRef]

29. Ichiyama, Y.; Koshiba, T.; Ito, H.; Tamura, A. Geochemistry and Magmatic Zircon U-Pb Dating of Amphibolite Blocks in the Omi Serpentinite Mélange, North Central Japan: Possible Subduction of the Cambrian Oceanic Crust. J. Mineral. Petrol. Sci. 2020, 115, 313-321. [CrossRef]

30. Ichiyama, Y.; Ito, H.; Hokanishi, N.; Tamura, A.; Arai, S. Plutonic Rocks in the Mineoka-Setogawa Ophiolitic Mélange, Central Japan: Fragments of Middle to Lower Crust of the Izu-Bonin-Mariana Arc? Lithos 2017, 282-283, 420-430. [CrossRef]

31. Sawada, H.; Isozaki, Y.; Sakata, S. Fragments of the Early Paleozoic Orogenic Belt from Tokyo Metropolis, Japan. J. Geol. Soc. Jpn. 2020, 126, 2020-2026. [CrossRef]

32. Sawada, H.; Isozaki, Y.; Aoki, S.; Sakata, S.; Sawaki, Y.; Hasegawa, R.; Nakamura, Y. The Late Jurassic Magmatic Protoliths of the Mikabu Greenstones in SW Japan: A Fragment of an Oceanic Plateau in the Paleo-Pacific Ocean. J. Asian Earth Sci. 2019, 169, 228-236. [CrossRef]

33. Tominaga, K.; Hara, H. Paleogeography of Late Jurassic Large-Igneous-Province Activity in the Paleo-Pacific Ocean: Constraints from the Mikabu Greenstones and Chichibu Accretionary Complex, Kanto Mountains, Central Japan. Gondwana Res. 2021, 89, 177-192. [CrossRef]

34. Fu, B.; Valley, J.W.; Kita, N.T.; Spicuzza, M.J.; Paton, C.; Tsujimori, T.; Bröcker, M.; Harlow, G.E. Multiple Origins of Zircons in Jadeitite. Contrib. Mineral. Petrol. 2010, 159, 769-780. [CrossRef]

35. Miyamoto, T.; Yanagi, T. U-Pb Dating of Zircon in Jadeite Rock in Oosayama Serpentinite Melange from Okayama Pref., Southwest Japan. Joint Annual Meeting of the Japanese Association of Mineralogists, Petrologists, and Economic Geologists, and The Mineral Society of Japan. Abstract 1998, 15, 190.

36. Tsujimori, T.; Liou, J.G.; Wooden, J.; Miyamoto, T. U-Pb Dating of Large Zircons in Low-Temperature Jadeitite from the Osayama Serpentinite Mélange, Southwest Japan: Insights into the Timing of Serpentinization. Int. Geol. Rev. 2005, 47, $1048-1057$. [CrossRef]

37. Ozawa, K.; Maekawa, H.; Shibata, K.; Asahara, Y.; Yoshikawa, M. Evolution Processes of Ordovician-Devonian Arc System in the South-Kitakami Massif and Its Relevance to the Ordovician Ophiolite Pulse. Island Arc 2015, 24, 73-118. [CrossRef] 
38. Ishiwatari, A. Time-Space Distribution and Petrologic Diversity of Japanese Ophiolites; Springer: Dordrecht, The Netherlands, 1991; pp. 723-743.

39. Kurokawa, K. Petrology of the Oeyama Ophiolitic Complex in the Inner Zone of Southwest Japan. Ser. E (Geol. Mineral.) Sci. Rep. Niigata Univ. 1985, 6, 37-113.

40. Tsujimori, T. Petrogenesis of the Fuko Pass High-Pressure Metacumulate from the Oeyama Peridotite Body, Southwestern Japan: Evidence for Early Paleozoic Subduction Metamorphism. Mem. Geol. Soc. Jpn. 1999, 52, 287-302.

41. Tsujimori, T.; Ishiwatari, A.; Banno, S. Discovery of Eclogitic Glaucophane Schist from the Omi Area, Renge Metamorphic Belt, the Inner Zone of South Western Japan. J. Geol. Soc. Jpn. 2000, 106, 1-2. [CrossRef]

42. Nishimura, Y.; Shibata, K. Modes of Occurrence and K-Ar Ages Ofmetagabbroic Rocks in the "Sangun Metamorphic Belt", Southwest Japan. Mem. Geol. Soc. Jpn. 1989, 33, 343-357.

43. Shibata, K.; Uchiumi, S.; Nakagawa, T. K-Ar Age Results-1. Bull. Geol. Surv. Jpn. 1979, 30, 675-686.

44. Tsujimori, T.; Itaya, T. Blueschist-facies Metamorphism during Paleozoic Orogeny in Southwestern Japan: Phengite K-Ar Ages of Blueschist-facies Tectonic Blocks in a Serpentinite Melange beneath Early Paleozoic Oeyama Ophiolite. Isl. Arc 1999, 8, 190-205. [CrossRef]

45. Abduriyim, A.; Saruwatari, K.; Katsurada, Y. Apanese Jadeite: History, Characteristics, and Comparison with Other Sources Gems Gemol. 2017, 53, 48-67. [CrossRef]

46. Takasu, A.; Sakamoto, S.; Kashiwabara, Y. Mineral Paragenesis and Chemical Compositions of the Constituent Minerals of Jadeitites from the Osayama Area $\mathrm{m}$ the Sangun Metamorphic Belt, Southwest Japan. Bull. Fac. Sci. Technol. Shimane Univ. Ser. A $2000,34,1-12$

47. Tsutsumi, Y.; Yokoyama, K.; Kasatkin, S.A.; Golozubov, V.v. Zircon U-Pb Age of Granitoids in the Maizuru Belt, Southwest Japan and the Southernmost Khanka Massif, Far East Russia. J. Mineral. Petrol. Sci. 2014, 109, 97-102. [CrossRef]

48. Kunugiza, K.; Nakamaru, E.; Goto, A.; Kobayashi, K.; Ota, T.; Miyajima, H.; Yokoyama, K. In-Situ U-Pb Zircon Age Dating Deciphering the Formation Event of the Omphacite Growth over Relict Edenitic Pargasite in Omphacite-Bearing Jadeitite of the Itoigawa-Omi Area of the Hida-Gaien Belt, Central Japan. J. Mineral. Petrol. Sci. 2017, 112, 256-270. [CrossRef]

49. Yokoyama, T.D.; Suzuki, T.; Kon, Y.; Hirata, T. Determinations of Rare Earth Element Abundance and U-Pb Age of Zircons Using Multispot Laser Ablation-Inductively Coupled Plasma Mass Spectrometry. Anal. Chem. 2011, 83, 8892-8899. [CrossRef]

50. Makino, Y.; Kuroki, Y.; Hirata, T. Determination of Major to Trace Elements in Metallic Materials Based on the Solid Mixing Calibration Method Using Multiple Spot-Laser Ablation-ICP-MS. J. Anal. At. Spectrom. 2019, 34, 1794-1799. [CrossRef]

51. Obayashi, H.; Tanaka, M.; Hattori, K.; Sakata, S.; Hirata, T. In Situ 207 Pb/ 206 Pb Isotope Ratio Measurements Using Two Daly Detectors Equipped on an ICP-Mass Spectrometer. J. Anal. At. Spectrom. 2017, 32, 686-691. [CrossRef]

52. Hattori, K.; Sakata, S.; Tanaka, M.; Orihashi, Y.; Hirata, T. U-Pb Age Determination for Zircons Using Laser Ablation-ICP-Mass Spectrometry Equipped with Six Multiple-Ion Counting Detectors. J. Anal. At. Spectrom. 2017, 32, 88-95. [CrossRef]

53. Sawaki, Y.; Asanuma, H.; Abe, M.; Hirata, T. U-Pb Ages of Granitoids around the Kofu Basin: Implications for the Neogene Geotectonic Evolution of the South Fossa Magna Region, Central Japan. Isl. Arc 2020, 29, e12361. [CrossRef]

54. Jochum, K.P.; Nohl, U.; Herwig, K.; Lammel, E.; Stoll, B.; Hofmann, A.W. GeoReM: A New Geochemical Database for Reference Materials and Isotopic Standards. Geostand. Geoanalytical Res. 2005, 29, 333-338. [CrossRef]

55. Jackson, S.E.; Pearson, N.J.; Griffin, W.L.; Belousova, E.A. The Application of Laser Ablation-Inductively Coupled Plasma-Mass Spectrometry to in Situ U-Pb Zircon Geochronology. Chem. Geol. 2004, 211, 47-69. [CrossRef]

56. Iwano, H.; Orihashi, Y.; Hirata, T.; Ogasawara, M.; Danhara, T.; Horie, K.; Hasebe, N.; Sueoka, S.; Tamura, A.; Hayasaka, Y.; et al. An Inter-Laboratory Evaluation of OD-3 Zircon for Use as a Secondary U-Pb Dating Standard. Isl. Arc 2013, 22, 382-394. [CrossRef]

57. Iizuka, T.; Hirata, T. Improvements of Precision and Accuracy in in Situ Hf Isotope Microanalysis of Zircon Using the Laser Ablation-MC-ICPMS Technique. Chem. Geol. 2005, 220, 121-137. [CrossRef]

58. Hu, Z.; Liu, Y.; Gao, S.; Liu, W.; Zhang, W.; Tong, X.; Lin, L.; Zong, K.; Li, M.; Chen, H.; et al. Improved in Situ Hf Isotope Ratio Analysis of Zircon Using Newly Designed X Skimmer Cone and Jet Sample Cone in Combination with the Addition of Nitrogen by Laser Ablation Multiple Collector ICP-MS. J. Anal. At. Spectrom. 2012, 27, 1391. [CrossRef]

59. Thirlwall, M.F.; Anczkiewicz, R. Multidynamic Isotope Ratio Analysis Using MC-ICP-MS and the Causes of Secular Drift in Hf $\mathrm{Nd}$ and Pb Isotope Ratios. Int. J. Mass Spectrom. 2004, 235, 59-81. [CrossRef]

60. Chu, N.-C.; Taylor, R.N.; Chavagnac, V.; Nesbitt, R.W.; Boella, R.M.; Milton, J.A.; German, C.R.; Bayon, G.; Burton, K. Hf Isotope Ratio Analysis Using Multi-Collector Inductively Coupled Plasma Mass Spectrometry: An Evaluation of Isobaric Interference Corrections. J. Anal. At. Spectrom. 2002, 17, 1567-1574. [CrossRef]

61. Russell, W.A.; Papanastassiou, D.A.; Tombrello, T.A. Ca Isotope Fractionation on the Earth and Other Solar System Materials Geochim. Et Cosmochim. Acta 1978, 42, 1075-1090. [CrossRef]

62. Patchett, P.J.; Tatsumoto, M. A Routine High-Precision Method for Lu-Hf Isotope Geochemistry and Chronology. Contrib. Mineral. Petrol. 1981, 75, 263-267. [CrossRef]

63. Gain, S.E.M.; Gréau, Y.; Henry, H.; Belousova, E.; Dainis, I.; Griffin, W.L.; O’Reilly, S.Y. Mud Tank Zircon: Long-Term Evaluation of a Reference Material for U-Pb Dating, Hf-Isotope Analysis and Trace Element Analysis. Geostand. Geoanalytical Res. 2019, 43, 339-354. [CrossRef] 
64. Wiedenbeck, M.; Hanchar, J.M.; Peck, W.H.; Sylvester, P.; Valley, J.; Whitehouse, M.; Kronz, A.; Morishita, Y.; Nasdala, L.; Fiebig, J.; et al. Further Characterisation of the 91500 Zircon Crystal. Geostand. Geoanalytical Res. 2004, 28, 9-39. [CrossRef]

65. Black, L.P.; Kamo, S.L.; Allen, C.M.; Davis, D.W.; Aleinikoff, J.N.; Valley, J.W.; Mundil, R.; Campbell, I.H.; Korsch, R.J.; Williams, I.S.; et al. Improved 206Pb/238U Microprobe Geochronology by the Monitoring of a Trace-Element-Related Matrix Effect; SHRIMP, ID-TIMS, ELA-ICP-MS and Oxygen Isotope Documentation for a Series of Zircon Standards. Chem. Geol. 2004, 205, 115-140. [CrossRef]

66. Woodhead, J.D.; Hergt, J.M. A Preliminary Appraisal of Seven Natural Zircon Reference Materials for In Situ Hf Isotope Determination. Geostand. Geoanalytical Res. 2005, 29, 183-195. [CrossRef]

67. Jochum, K.P.; Weis, U.; Stoll, B.; Kuzmin, D.; Yang, Q.; Raczek, I.; Jacob, D.E.; Stracke, A.; Birbaum, K.; Frick, D.A.; et al. Determination of Reference Values for NIST SRM 610-617 Glasses Following ISO Guidelines. Geostand. Geoanalytical Res. 2011, 35, 397-429. [CrossRef]

68. Vermeesch, P. IsoplotR: A Free and Open Toolbox for Geochronology. Geosci. Front. 2018, 9, 1479-1493. [CrossRef]

69. Bouvier, A.; Vervoort, J.D.; Patchett, P.J. The Lu-Hf and Sm-Nd Isotopic Composition of CHUR: Constraints from Unequilibrated Chondrites and Implications for the Bulk Composition of Terrestrial Planets. Earth Planet. Sci. Lett. 2008, 273, 48-57. [CrossRef]

70. Nowell, G.M.; Kempton, P.D.; Noble, S.R.; Fitton, J.G.; Saunders, A.D.; Mahoney, J.J.; Taylor, R.N. High Precision Hf Isotope Measurements of MORB and OIB by Thermal Ionisation Mass Spectrometry: Insights into the Depleted Mantle. Chem. Geol. 1998, 149, 211-233. [CrossRef]

71. Williams, I.S.; Buick, I.S.; Cartwright, I. An Extended Episode of Early Mesoproterozoic Metamorphic Fluid Flow in the Reynolds Range, Central Australia. J. Metamorph. Geol. 2004, 14, 29-47. [CrossRef]

72. Hoskin, P.W.O.; Ireland, T.R. Rare Earth Element Chemistry of Zircon and Its Use as a Provenance Indicator. Geology 2000, $28,627$. [CrossRef]

73. Buriánek, D.; Janoušek, V.; Hanžl, P.; Jiang, Y.; Schulmann, K.; Lexa, O.; Altanbaatar, B. Petrogenesis of the Late Carboniferous Sagsai Pluton in the SE Mongolian Altai. J. Geosci. (Czech Repub.) 2016, 61, 67-92. [CrossRef]

74. Balaghi Einalou, M.; Sadeghian, M.; Zhai, M.; Ghasemi, H.; Mohajjel, M. Zircon U-Pb Ages, Hf Isotopes and Geochemistry of the Schists, Gneisses and Granites in Delbar Metamorphic-Igneous Complex, SE of Shahrood (Iran): Implications for Neoproterozoic Geodynamic Evolutions of Central Iran. J. Asian Earth Sci. 2014, 92, 92-124. [CrossRef]

75. Gan, B.; Li, Z.; Song, Z.; Li, J. Middle Cambrian Granites in the Dunhuang Block (NW China) Mark the Early Subduction of the Southernmost Paleo-Asian Ocean. Lithos 2020, 372-373, 105654. [CrossRef]

76. Feng, Z.; Liu, Y.; Li, L.; She, H.; Jiang, L.; Du, B.; Liu, Y.; Li, W.; Wen, Q.; Liang, C. Subduction, Accretion, and Collision during the Neoproterozoic-Cambrian Orogeny in the Great Xing'an Range, NE China: Insights from Geochemistry and Geochronology of the Ali River Ophiolitic Mélange and Arc-Type Granodiorites. Precambrian Res. 2018, 311, 117-135. [CrossRef]

77. Chen, Y.-X.; Gao, P.; Zheng, Y.-F. The Anatectic Effect on the Zircon Hf Isotope Composition of Migmatites and Associated Granites. Lithos 2015, 238, 174-184. [CrossRef]

78. Hoffmann, J.E.; Münker, C.; Polat, A.; König, S.; Mezger, K.; Rosing, M.T. Highly Depleted Hadean Mantle Reservoirs in the Sources of Early Archean Arc-like Rocks, Isua Supracrustal Belt, Southern West Greenland. Geochim. Cosmochim. Acta 2010, 74, 7236-7260. [CrossRef]

79. Choi, S.; Mukasa, S.; Andronikov, A.; Osanai, Y.; Harley, S.; Kelly, N. Lu-Hf Systematics of the Ultra-High Temperature Napier Metamorphic Complex in Antarctica: Evidence for the Early Archean Differentiation of Earth's Mantle. Earth Planet. Sci. Lett. 2006, 246, 305-316. [CrossRef]

80. Morino, P.; Caro, G.; Reisberg, L. Differentiation Mechanisms of the Early Hadean Mantle: Insights from Combined 176Hf142,143Nd Signatures of Archean Rocks from the Saglek Block. Geochim. Cosmochim. Acta 2018, 240, 43-63. [CrossRef]

81. Wang, Y.-F.; Li, X.-H.; Jin, W.; Zhang, J.-H. Eoarchean Ultra-Depleted Mantle Domains Inferred from ca. 3.81 Ga Anshan Trondhjemitic Gneisses, North China Craton. Precambrian Res. 2015, 263, 88-107. [CrossRef] 